\title{
Effect of Histamine and Histamine Antagonists on Natural and Antibody-Dependent Cellular Cytotoxicity of Human Lymphocytes in Vitro ${ }^{1}$
}

\author{
MadhaVan P. N. NAIR ${ }^{2}$ AND Stanley A. SCHWARTZ ${ }^{3}$ \\ The University of Michigan, Departments of Pediatrics and Epidemiology, Ann Arbor, Michigan 48109
}

Received December 7, 1982; accepted June 13, 1983

\begin{abstract}
The in vitro effect of histamine and its antagonists, cimetidine and clemastine fumarate, on natural killer (NK) and antibody-dependent cellular cytotoxicity (ADCC) activities of human lymphocytes was investigated. The histamine $1(\mathrm{HI})$ antagonist, clemastine fumarate, and the histamine $2(\mathrm{H} 2)$ antagonist, cimetidine, but not histamine alone, inhibited the NK and ADCC activities of lymphocytes when added directly to the mixture of effector and target cells in a ${ }^{51} \mathrm{Cr}$-release assay. This inhibition was proportional to the concentration of drugs added and was observed at various effector to target ratios against several targets. $\mathrm{H} 1$ and $\mathrm{H} 2$ antagonists also inhibited NK activities of $\mathrm{T}$ cells as well as Percoll-separated, NK-enriched effector cells. The inhibition was significantly reversed by histamine. In target binding assays, clemastine fumarate and cimetidine also decreased the target binding capacity of effector lymphocytes. Further, PBL precultured with histamine $\left(10^{-3}-10^{-4} \mathrm{M}\right)$ for $24 \mathrm{hr}$ showed a significant decrease in their NK and ADCC activities. In coculture experiments, PBL precultured with histamine suppressed the NK activity of normal autologous effector lymphocytes. PBL precultured with histamine showed an increased number of $\mathrm{OKT}^{+}$cells, as estimated using monoclonal antibodies. The suppression of cytotoxicity was not due to either direct toxicity, steric hindrance, crowding, or cell death, but by functionally viable suppressor cells. An immunoregulatory role for histamine in NK and ADCC reactions is proposed.
\end{abstract}

\section{INTRODUCTION}

We and our co-workers have previously demonstrated that unstimulated, cultured human peripheral blood lymphocytes $(\mathrm{PBL})^{4}$ can develop suppressor cell activities against lymphocyte transformation, polyclonal B-cell activation, and natural killer (NK) and antibody-dependent cellular cytotoxicity (ADCC) reactions, as a possible consequence of an autologous mixed-lymphocyte culture reaction (1-3). We have also shown that serum-free culture supernatants of unstimulated PBL contain soluble

\footnotetext{
${ }^{1}$ Aided by National Institutes of Health Grant AI-16216 and a grant from the Children's Leukemia Foundation of Michigan.

${ }^{2}$ To whom requests for reprints should be addressed: Department of Epidemiology, 2022 School of Public Health I, University of Michigan, Ann Arbor, Mich. 48109.

${ }^{3}$ Recipient of NIH Research Career Development Award 1-K04-CA-00896.

${ }^{4}$ Abbreviations used: ADCC, antibody-dependent cellular cytotoxicity; CEM, human T-lymphoblastoid cell line; E:T, effector to target ratio; H1, histamine 1 receptor; $\mathrm{H} 2$, histamine 2 receptor; K562, human erythroleukemia cell line; NK, natural killer; PBL, peripheral blood lymphocytes depleted of adherent cells; $\mathrm{SB}$, human B-leukemia cell line; TBC, target binding cells; T $\gamma$, T cells with Fc receptors for IgG.
} 
suppressor factor(s) (SSF) that significantly exhibit suppressor activity toward mitogenesis and alloantigen stimulation in mixed-lymphocyte culture (4), and NK and ADCC reactions (5). Other studies on T-lymphocyte subpopulations have shown that $\mathrm{T}$ cells bearing $\mathrm{Fc}$ receptors for human $\mathrm{IgG}(\mathrm{T} \gamma)$ mediate both $\mathrm{NK}$ and ADCC activities $(6,7)$ and exhibit suppressive effects on various lymphocyte reactions $(8-10)$.

The role of histamine, a vasoactive amine, in immunoregulation has been extensively studied. In vitro investigations showed that histamine inhibits cell-mediated cytotoxicity, lymphocyte proliferative responses to mitogens and soluble antigens, lymphokine production, and the mixed-lymphocyte reaction (11-15). Our interest in immunoregulation of natural and antibody-dependent cellular cytotoxicity of human lymphocytes led us to investigate the effect of histamine and histamine antagonists on NK and ADCC activities of human lymphocytes. The results indicate that lymphocytes precultured with histamine demonstrated a significant decrease in their NK and ADCC activities and were able to suppress the NK activity of autologous effector cells in coculture experiments. An immunoregulatory role of histamine in cellular cytotoxic reactions is thus proposed.

\section{MATERIALS AND METHODS}

Drugs. The $\mathrm{H} 1$ receptor blocker, clemastine fumarate (Tavist, Dorsey Labs, Lincoln, Nebr.), was used in a concentration range of $1 \times 10^{-8}$ to $1 \times 10^{-5} \mathrm{M}$; whereas the $\mathrm{H} 2$ receptor blocker, cimetidine (Smith-Kline and French Labs, Philadelphia, $\mathrm{Pa}$.), was used in a concentration range of $1 \times 10^{-4}$ to $2.5 \times 10^{-2} \mathrm{M}$. Histamine (Sigma Chemical Co., St. Louis, Mo.) was used in concentrations of $1 \times 10^{-5}$ to $1 \times 10^{-2} M$.

Experimental design. Drugs were added directly to the mixture of effector and target cells in a 4-hr ${ }^{51} \mathrm{Cr}$-release assay. Controls containing either target and effector cells, or targets and drugs, were run concomitantly. In separate experiments, lymphocytes were also precultured with histamine for 0 to $24 \mathrm{hr}$, washed, and tested for NK and ADCC activities or used in mixing experiments to measure their suppressive effects on autologous lymphocytes.

Monoclonal antibodies. OKT3, OKT4, and OKT8 antibodies were purchased from the Ortho Pharmaceutical Corporation, Raritan, New Jersey and were used in a final dilution of 1:100. These antibodies are complement $(\mathrm{C})$ fixing and of the IgG isotype.

Lymphocyte donors. Peripheral blood from adult healthy donors of both sexes was drawn into a plastic syringe containing heparin $(20 \mathrm{U} / \mathrm{ml})$. Donors were apprised of the study and consents were obtained consistent with the policies of The University of Michigan and the National Institutes of Health.

Isolation of lymphocytes. PBL were isolated from heparinized venous blood using a modified method of Böyum (16). Blood was diluted with an equal volume of normal saline and centrifuged at $400 \mathrm{~g}$ for $30 \mathrm{~min}$ at $18^{\circ} \mathrm{C}$. The mononuclear cell band was harvested, washed three times with saline, and resuspended in RPMI 1640 medium, containing $25 \mathrm{~m} M$ HEPES buffer supplemented with $5 \%$ heat-inactivated fetal calf serum (FCS) (GIBCO, Grand Island, N.Y.), $80 \mu \mathrm{g} / \mathrm{ml}$ gentamicin (Shering Corp., Kenilworth, N.J.), and $300 \mu \mathrm{g}$ fresh glutamine/ml (complete medium).

Depletion of adherent cells. Mononuclear cells were depleted of adherent cells by passing through a G-10 column. PBL were suspended in RPMI 1640 with $10 \%$ FCS 
and passaged through a 7-ml column of Sephadex G-10 beads (Pharmacia Fine Chemicals, Piscataway, N.J.), equilibrated in the same medium. After $45 \mathrm{~min}$ of incubation at $37^{\circ} \mathrm{C}$, nonadherent cells were washed through with one bed volume of warm $\left(37^{\circ} \mathrm{C}\right)$ medium. The cell recovery was $>70 \%$ of the total input, and macrophage contamination as indicated by nonspecific esterase staining was $<2 \%$.

Preparation of $T$ cells. $T$ cells were prepared as described elsewhere (17). Briefly, $4 \times 10^{6}$ PBL depleted of adherent cells were mixed with $0.25 \mathrm{ml}$ of heat-inactivated FCS preabsorbed with sheep red blood cells (SRBC) and $1 \mathrm{ml}$ of $1 \%$ packed volume, neuraminidase-treated $(25 \mathrm{U} / \mathrm{ml}$ in a $5 \%$ SRBC suspension) SRBC. The mixture was incubated at $37^{\circ} \mathrm{C}$ for $5 \mathrm{~min}$ and centrifuged at $200 \mathrm{~g}$ for $5 \mathrm{~min}$ followed by incubation at $4^{\circ} \mathrm{C}$ for $1 \mathrm{hr}$. The pellets were gently resuspended and $\mathrm{T}$ cells rosetted with SRBC were separated from non-T lymphocytes on a Ficoll-Hypaque (Pharmacia) density gradient by centrifugation at $480 \mathrm{~g}$ for $20 \mathrm{~min}$ at $20^{\circ} \mathrm{C}$. SRBC attached to the isolated $\mathrm{T}$ lymphocytes (pellet) were lysed by hypotonic treatment with $1 \mathrm{ml}$ of distilled water, followed by $1 \mathrm{ml}$ of double-strength minimal essential medium (MEM, GIBCO). T cells were washed three times with RPMI 1640 and resuspended in complete medium and preincubated for $24 \mathrm{hr}$ before use.

Percoll fractionation of lymphocytes. The enrichment of NK effector cells using a discontinuous gradient of Percoll (Pharmacia) was carried out as described elsewhere (18). To prepare a discontinuous density gradient, Percoll solution was mixed at various concentrations with RPMI 1640 medium, and 2-ml aliquots (ranging from 50.0 to $37.5 \%$ in $2.5 \%$ increments) were gently layered into $15 \times 130-\mathrm{mm}$ roundbottom glass test tubes. Adherent cell-depleted lymphocytes were layered on top of the gradient and centrifuged at $300 \mathrm{~g}$ for $45 \mathrm{~min}$ at $20^{\circ} \mathrm{C}$. Six fractions, with the uppermost $(37.5 \%)$ designated " 0 " and the lowermost $(50.0 \%)$ designated "V," were collected from the top with a Pasteur pipet and washed twice in RPMI 1640 medium. The least dense fraction banding at the $37.5 \%$ Percoll interface consistently showed the highest NK activity and was used routinely as a source of NK-enriched cells. Recovery of cells was $85 \%$ of that input, and viability always exceeded $95 \%$ by trypan blue dye exclusion.

In vitro incubation of lymphocytes with histamine. Lymphocytes depleted of adherent cells, T cells, and Percoll-separated NK-enriched effector cells were suspended in complete medium at a concentration of $3 \times 10^{6}$ cells $/ \mathrm{ml}$ to which histamine was added. A duplicate set of cultures received RPMI 1640 medium instead of histamine as control. Cell cultures were incubated for 0 to $24 \mathrm{hr}$ in a humidified environment of $5 \% \mathrm{CO}_{2}$ in air at $37^{\circ} \mathrm{C}$. Cells were washed twice and resuspended in complete medium. Cell viability was comparable with that of control cultures as determined by trypan blue dye exclusion and was not affected by histamine concentrations of $\leqslant 1 \times 10^{-2} M$. Treated and control cultures were tested for their ability to mediatc NK and ADCC activities.

Tumor target cells. The human erythroleukemia cell line, K562, and T-lymphoblastoid cell line, CEM, were used as targets for NK cells. For the ADCC assay, we chose as targets a human B-cell leukemia line (SB) because of resistance to NK activity in a 4 -hr ${ }^{51} \mathrm{Cr}$-release assay.

Preparation of target cells. Passaged 48-hr-old target cells were washed twice with complete medium. To $0.8 \mathrm{ml}$ aliquots of complete medium containing $5 \times 10^{6}$ tumor cells, $200 \mu \mathrm{Ci}$ of ${ }^{51} \mathrm{Cr}$ as sodium chromate (New England Nuclear, Boston, Mass.) was added. The cells were incubated at $37^{\circ} \mathrm{C}$ for $1 \mathrm{hr}$ in a humidified atmosphere 
of $5 \% \mathrm{CO}_{2}$ in air with intermittent shaking. Following incubation, the cells were washed three times with complete medium and resuspended to a concentration of $2 \times 10^{5}$ cells $/ \mathrm{ml}$.

Assay for NK activity. NK activity was determined in a direct ${ }^{51} \mathrm{Cr}$-release assay as previously described $(3,5,19,20)$. Briefly, varying concentrations of viable effector cells in complete medium were added to triplicate cultures of ${ }^{51} \mathrm{Cr}$-labeled target cells in 0.2-ml volumes in V-bottom microtitration plates (Dynatech Labs, Alexandria, Va.). After centrifugation at $40 \mathrm{~g}$ for $2 \mathrm{~min}$, they were incubated at $37^{\circ} \mathrm{C}$ in a humidified atmosphere of $5 \% \mathrm{CO}_{2}$ in air for $4 \mathrm{hr}$. Percentage cytotoxicity was calculated as

$$
\% \text { cytotoxicity }=\frac{\text { experimental release }- \text { spontaneous release }}{\text { total release }- \text { spontaneous release }} \times 100,
$$

where spontaneous release represents counts released from control wells containing only $2 \times 10^{4}$ target cells, and total release represents counts obtained in an aliquot of $2 \times 10^{4}$ lysed target cells.

Assay for $A D C C$. The ADCC activity of effector cells was determined by the original method of Perlmann and Perlmann (21) as modified by Handwerger and Koren (22). Briefly, $50 \mu \mathrm{l}$ of varying concentrations of effector cells was added to $50 \mu \mathrm{l}$ of complete medium containing ${ }^{51} \mathrm{Cr}$-labeled SB target cells and $100 \mu \mathrm{l}$ of a $2 \times 10^{-4}$ dilution of rabbit anti-SB antisera previously found to yield maximal ADCC. Percentage ADCC activity was calculated as described above for NK activity with the following exceptions. Spontaneous release represents counts released in control wells containing effector cells, labeled SB target cells, and medium instead of anti-SB antibodies, and total release represents counts obtained in an aliquot of $1 \times 10^{4}{ }^{51} \mathrm{Cr}$-labeled SB target cells. Percentage inhibition of NK and ADCC activities by drugs was calculated as

$$
\% \text { inhibition }=\frac{\begin{array}{c}
\% \text { cytotoxicity of control lymphocytes } \\
-\% \text { cytotoxicity of drug treated lymphocytes }
\end{array}}{\% \text { cytotoxicity of control lymphocytes }} \times 100 .
$$

Assay for complement-dependent cytotoxicity. Lymphocytes $\left(5 \times 10^{6}\right)$ were suspended in serum-free RPMI 1640 medium to which monoclonal antibodies were added to yield a final titer of 1:100 (previously found to be optimal). The cultures were incubated at room temperature for $30 \mathrm{~min}$. They were then washed twice with serum-free medium and suspended in a 1:4 final dilution of rabbit complement. The mixtures were incubated for $1 \mathrm{hr}$ at $37^{\circ} \mathrm{C}$ and washed twice with serum-free medium. The number of positive cells staincd with trypan blue was counted, using a hemacytometer.

Target binding assay. Target binding cell (TBC) assay was used as described by Haliotis et al. (23). In brief, lymphocytes precultured separately with either of the drugs, or without drugs, were washed twice and mixed with a fivefold excess of tumor cells centrifuged at $150 \mathrm{~g}$ for $5 \mathrm{~min}$ and incubated at $37^{\circ} \mathrm{C}$ for $5 \mathrm{~min}$. Following incubation, lymphocyte-target mixtures were transferred to ice, the pellets were gently resuspended, and the number of lymphocytes binding to tumor targets was determined, using a hemacytometer.

\section{RESULTS}

\section{Effect of Histamine on NK and ADCC Activities of Lymphocytes}

In view of the finding that human lymphocytes have histamine receptors, and such lymphocytes exert various immunoregulatory functions in man $(11-14,24-26)$, the 
influence of histamine on NK and ADCC activities of lymphocyte subpopulations was studied. Data presented in Table 1 show that histamine added at different concentrations ranging ${ }^{\text {ffom }} 1 \times 10^{-2}$ to $1 \times 10^{-5} \mathrm{M}$ to the reaction mixture of fresh effector and target cells and incubated for $4 \mathrm{hr}$ showed no significant effect on NK and ADCC activities of either total PBL or isolated T cells.

\section{Effect of Histamine Antagonists on NK and ADCC Activities of Lymphocytes}

Table 2 shows a dose-response effect of histamine antagonists, clemastine and cimetidine, on NK and ADCC activities of lymphocytes. Clemastine, at concentrations of $\geqslant 2.5 \times 10^{-5} \mathrm{M}$, and cimetidine, at concentrations of $\geqslant 5 \times 10^{-2} \mathrm{M}$, significantly inhibited NK and ADCC activities. Cimetidine at concentrations $<5 \times 10^{-2} \mathrm{M}$ consistently showed detectable suppression of NK and ADCC activities of lymphocytes, although the level of suppression was not significant. Therefore, a concentration of $5 \times 10^{-2} M$ which was not toxic to effector or target cells was used in subsequent experiments. The results suggest that histamine antagonists inhibit or block NK and ADCC reactions of lymphocytes.

Table 3 shows the inhibition of NK activity of lymphocytes against K562 and CEM targets and ADCC activity against SB targets at different E:T cell ratios by histamine and its antagonists. It is evident that the inhibitory effect of drugs occurs even at higher E:T cell ratios. No significant inhibition was obtained with histamine at any $E: T$ cell ratios.

The effect of histamine and its antagonists on NK and ADCC activities of lymphocyte subpopulations is presented in Table 4. The results demonstrate that $\mathrm{H} 1$ and $\mathrm{H} 2$ antagonists significantly inhibited NK and ADCC activities of both PBL and T cells. Histamine did not produce any significant effect on NK and ADCC activities of either PBL or T cells.

\section{TABLE 1}

Effect of Histamine on NK and ADCC Activities ${ }^{a}$

\begin{tabular}{|c|c|c|c|c|}
\hline \multirow{3}{*}{$\begin{array}{c}\text { Histamine } \\
\text { concentration } \\
(M)\end{array}$} & \multicolumn{4}{|c|}{ Cytotoxicity $(\%)^{b}$} \\
\hline & \multicolumn{2}{|c|}{$\mathrm{PBL}^{c}$} & \multicolumn{2}{|c|}{$\mathrm{T}$ cells ${ }^{d}$} \\
\hline & $\mathrm{NK}^{e}$ & $\mathrm{ADCC}^{f}$ & NK & ADCC \\
\hline 0 & $50.0 \pm 3.4$ & $36.1 \pm 5.2$ & $46.2 \pm 2.6$ & $34.3 \pm 2.5$ \\
\hline $1 \times 10^{-5}$ & $46.2 \pm 5.8$ & $38.2 \pm 1.3$ & $39.2 \pm 6.2$ & $31.8 \pm 2.8$ \\
\hline $1 \times 10^{-4}$ & $44.7 \pm 8.6$ & $35.0 \pm 3.0$ & $42.7 \pm 2.9$ & $28.6 \pm 3.2$ \\
\hline $1 \times 10^{-3}$ & $47.1 \pm 2.4$ & $35.6 \pm 5.5$ & $41.3 \pm 7.5$ & $30.0 \pm 3.2$ \\
\hline $1 \times 10^{-2}$ & $47.3 \pm 1.3$ & $34.4 \pm 3.5$ & $41.0 \pm 3.2$ & $27.7 \pm 4.2$ \\
\hline
\end{tabular}

\footnotetext{
${ }^{a}$ Histamine was added directly to the mixture of effector and target cells in a 4-hr ${ }^{51} \mathrm{Cr}$-release assay. Results are expressed as means \pm SEM of triplicate determinations from a representative experiment and four separate experiments gave similar results.

${ }^{b}$ Percentage cytotoxicity was calculated as described under Materials and Methods.

${ }^{c}$ PBL depleted of adherent cells as described under Materials and Methods.

${ }^{d} \mathrm{~T}$ cells separated by rosetting as described under Materials and Methods.

e NK activity was measured against the human erythroleukemia cell line, K562.

${ }^{f}$ ADCC activity was measured against the human B-lymphoblast cell line, SB, sensitized with anti-SB sera.
} 
TABLE 2

Dose-Response Effect of Antihistaminics on NK and ADCC Activities ${ }^{a}$

\begin{tabular}{|c|c|c|c|}
\hline \multirow[b]{2}{*}{ Drug } & \multirow{2}{*}{$\begin{array}{c}\text { Concentration } \\
(M)\end{array}$} & \multicolumn{2}{|c|}{ Cytotoxicity (\%) ${ }^{b}$} \\
\hline & & $\mathrm{NK}^{c}$ & $\mathrm{ADCC}^{d}$ \\
\hline None & - & $70.2 \pm 2.4$ & $50.8 \pm 2.4$ \\
\hline Clemastine fumarate & $\begin{array}{r}1 \times 10^{-8} \\
1 \times 10^{-7} \\
5 \times 10^{-7} \\
5 \times 10^{-6} \\
7.5 \times 10^{-6} \\
2.5 \times 10^{-6} \\
1 \times 10^{-5}\end{array}$ & $\begin{array}{c}74.0 \pm 3.2 \\
72.0 \pm 2.1 \\
66.5 \pm 1.1 \\
63.5 \pm 8.4 \\
64.8 \pm 5.3 \\
38.4 \pm 2.3^{*} \\
9.0 \pm 4.3^{* *}\end{array}$ & $\begin{array}{l}52.0 \pm 2.7 \\
49.2 \pm 4.2 \\
45.7 \pm 3.2 \\
48.7 \pm 4.2 \\
47.5 \pm 2.2 \\
37.6 \pm 4.3^{*} \\
10.7 \pm 11.8^{* *}\end{array}$ \\
\hline Cimetidine & $\begin{aligned} 1 & \times 10^{-4} \\
5 & \times 10^{-4} \\
7.5 & \times 10^{-3} \\
5 & \times 10^{-3} \\
2.5 & \times 10^{-2}\end{aligned}$ & $\begin{array}{l}72.0 \pm 2.8 \\
50.9 \pm 4.8 \\
43.7 \pm 2.4 \\
26.2 \pm 1.4^{*} \\
10.2 \pm 2.8^{* *}\end{array}$ & $\begin{array}{l}52.0 \pm 2.8 \\
46.3 \pm 4.3 \\
43.3 \pm 4.9 \\
20.8 \pm 3.9^{*} \\
13.7 \pm 3.3^{* *}\end{array}$ \\
\hline
\end{tabular}

\footnotetext{
${ }^{a}$ Drugs were added directly to the mixture of effector and target cells in a 4-hr assay at a 50:1 E:T ratio.

${ }^{b}$ Percentage cytotoxicity was calculated as described under Materials and Methods. Results are expressed as means \pm SEM of four experiments.

${ }^{c}$ NK activity was measured against the human erythroleukemia cell line, K562.

${ }^{d}$ ADCC activity was measured against the human B-lymphoblast cell line, SB, sensitized with anti-SB

$* P<0.05$.

** $P<0.01$.
} sera.

Data presented in Table 5 reveal the effect of drugs on Percoll-separated NKenriched effector cells. Clemastine and cimetidine significantly inhibited NK activity of enriched effector cells while histamine did not manifest any significant effect on NK activity.

To determine whether the addition of histamine reduces the inhibitory effect of antihistaminics, we added histamine together with antihistaminics to the test system in a 4-hr assay (Table 6). Addition of either clemastine and cimetidine alone to the reaction mixture significantly inhibited NK and ADCC activities of lymphocytes. The inhibitory effect of clemastine and cimetidine was markedly reduced by the simultaneous addition of histamine. The same concentration of histamine $\left(1 \times 10^{-3}\right.$ $M$ ) used alone in the system did not produce any significant effect on either NK or ADCC activity of lymphocytes.

\section{Effect of Histamine Antagonists on Target Binding Cells}

To examine whether the suppression of cytotoxicity of lymphocytes by histamine antagonists is due to interference with a histamine receptor-associated target recognition structure rather than inhibition of the lytic mechanism, target binding assays were performed. The results of such studies are presented in Table 7. Clemastine $(2.5$ $\left.\times 10^{-5} \mathrm{M}\right)$ and cimetidine $\left(5 \times 10^{-2} \mathrm{M}\right)$, at $\mathrm{NK}$ and ADCC inhibitory concentrations, significantly reduced the percentage of target binding lymphocytes (19 and $13 \%$, respectively) compared to control lymphocytes $(37 \%)$. Histamine at either $1 \times 10^{-3}$ or $1 \times 10^{-7} M$ concentrations did not affect the target binding ability of lymphocytes. 


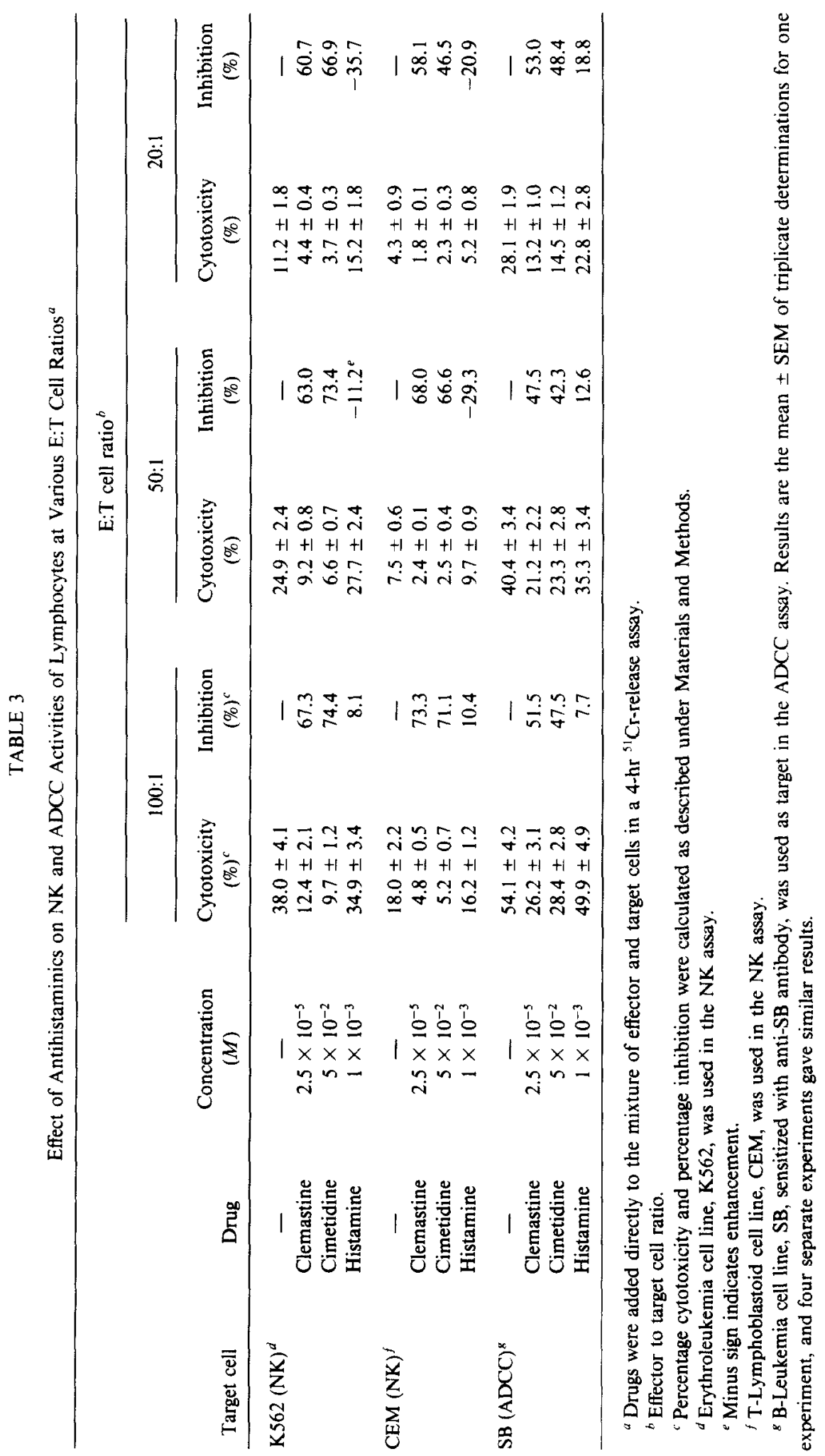




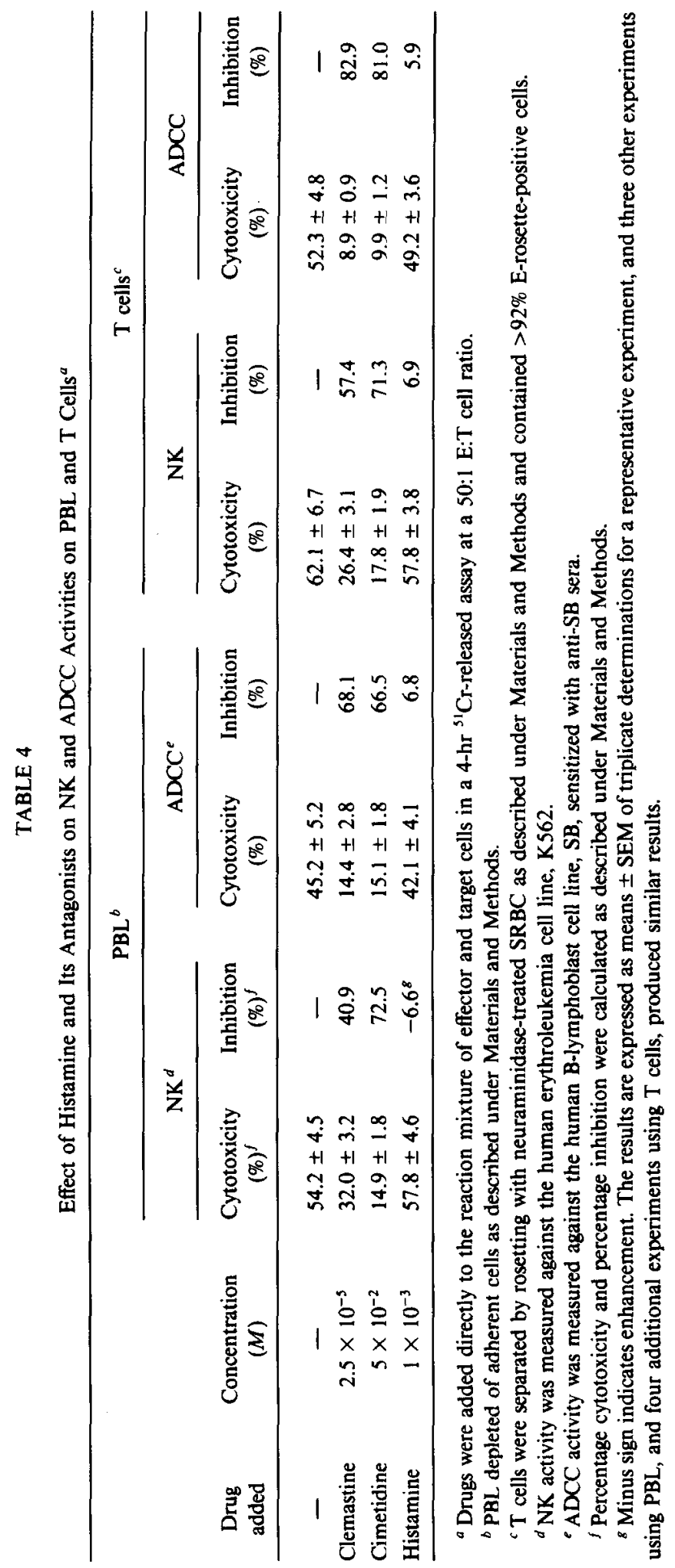


TABLE 5

Effect of Antihistaminics on Percoll-Enriched NK Effector Cells ${ }^{a}$

\begin{tabular}{lccc}
\hline \multicolumn{1}{c}{ Drug } & $\begin{array}{c}\text { Concentration } \\
(M)\end{array}$ & $\begin{array}{c}\text { Cytotoxicity } \\
(\%)^{b}\end{array}$ & $\begin{array}{c}\text { Inhibition } \\
(\%)^{\circ}\end{array}$ \\
None & - & $28.0 \pm 2.8$ & \\
Clemastine & $2.5 \times 10^{-5}$ & $14.0 \pm 1.0$ & 50.0 \\
Cimetidine & $5 \times 10^{-2}$ & $6.8 \pm 0.7$ & 75.0 \\
Histamine & $1 \times 10^{-3}$ & $29.4 \pm 3.2$ & $-5.0^{\circ}$ \\
\hline
\end{tabular}

${ }^{\circ}$ Drugs were added directly to the mixture of effector and target cells in a $4-\mathrm{hr}{ }^{51} \mathrm{Cr}$-release assay at a 10:1 E:T ratio.

${ }^{b}$ Percentage cytotoxicity and percentage inhibition were calculated as described under Materials and Methods. Results are expressed as means \pm SEM of triplicate determinations for a representative experiment, and four separate experiments gave similar results.

${ }^{c}$ Minus sign indicates enhancement.

These results demonstrate that histamine antagonists affect the target recognition structure of lymphocytes rather than their lytic potential.

\section{Preculture of Lymphocytes with Histamine Suppresses NK and ADCC Activities}

Figure 1 reveals the results of a time-course study of PBL precultured with different concentrations of histamine for its effect on NK and ADCC activities. PBL precultured with histamine $\left(1 \times 10^{-2}\right.$ to $\left.1 \times 10^{-4} \mathrm{M}\right)$ for 0 to $12 \mathrm{hr}$ were unaffected regarding their NK and ADCC activities. PBL precultured with histamine for $24 \mathrm{hr}$ showed significant suppressive effects on their NK and ADCC functions. Maximal effect on NK (38\% suppression) and ADCC (32\% suppression) activities was obtained with a

TABLE 6

Effect of Histamine on Inhibition of NK and ADCC Activities by Histamine Antagonists ${ }^{\circ}$

\begin{tabular}{|c|c|c|c|c|c|}
\hline \multirow[b]{2}{*}{ Drug added } & \multirow[b]{2}{*}{$\begin{array}{c}\text { Concentration } \\
(M)\end{array}$} & \multicolumn{2}{|c|}{$\mathrm{NK}^{b}$} & \multicolumn{2}{|c|}{$\mathrm{ADCC}^{\mathrm{C}}$} \\
\hline & & $\begin{array}{c}\text { Cytotoxicity } \\
(\%)^{d}\end{array}$ & $\begin{array}{l}\text { Inhibition } \\
(\%)^{d}\end{array}$ & $\begin{array}{c}\text { Cytotoxicity } \\
(\%)\end{array}$ & $\begin{array}{c}\text { Inhibition } \\
(\%)\end{array}$ \\
\hline None & - & $47.8 \pm 4.2$ & - & $35.0 \pm 3.3$ & - \\
\hline Clemastine & $2.5 \pm 10^{-5}$ & $14.2 \pm 1.8$ & 70.2 & $20.4 \pm 2.1$ & 41.7 \\
\hline Cimetidine & $5.0 \times 10^{-2}$ & $18.0 \pm 1.9$ & 62.3 & $13.5 \pm 1.6$ & 61.4 \\
\hline Histamine & $1.0 \times 10^{-3}$ & $45.0 \pm 3.7$ & 5.8 & $33.0 \pm 2.4$ & 5.7 \\
\hline $\begin{array}{l}\text { Clemastine } \\
+ \text { histaminc }\end{array}$ & $\begin{array}{l}2.5 \times 10^{-5} \\
1.0 \times 10^{-3}\end{array}$ & $29.2 \pm 3.1$ & 38.9 & $30.2 \pm 4.0$ & 13.7 \\
\hline $\begin{array}{l}\text { Cimetidine } \\
\quad+\text { histamine }\end{array}$ & $\begin{array}{l}5.0 \times 10^{-2} \\
1.0 \times 10^{-3}\end{array}$ & $32.4 \pm 3.0$ & 32.2 & $27.6 \pm 3.6$ & 21.1 \\
\hline
\end{tabular}

${ }^{a}$ Drugs were added directly to the mixture of effector PBL depleted of adherent cells and target cells at a 50:1 E:T ratio in a 4-hr ${ }^{51} \mathrm{Cr}$-release assay. Results are the mean \pm SEM of triplicate determinations for one experiment, and four separate experiments gave similar results.

${ }^{b} \mathrm{NK}$ activity was measured against the human erythroleukemia cell line, K\$62.

${ }^{c} \mathrm{ADCC}$ activity was measured against the human B-lymphoblastoid cell line, SB, sensitized with antiSB sera.

${ }^{d}$ Percentage cytotoxicity and percentage inhibition were calculated as described under Materials and Methods. 
TABLE 7

Effect of Antihistaminics on Binding of Target Cells by NK Lymphocytes ${ }^{2}$

\begin{tabular}{lccc}
\hline \multicolumn{1}{c}{ Drug } & $\begin{array}{c}\text { Concentration } \\
(M)\end{array}$ & $\begin{array}{c}\text { Target binding cells } \\
(\%)\end{array}$ & $\begin{array}{c}\text { Inhibition of target } \\
\text { binding cells (\%) }\end{array}$ \\
\hline None & - & $37 \pm 3.2$ & - \\
Clemastine & $2.5 \times 10^{-5}$ & $19 \pm 1.8$ & 48.6 \\
& $1 \times 10^{-7}$ & $40 \pm 2.7$ & $-8.1^{b}$ \\
Cimetidine & $5 \times 10^{-2}$ & $13 \pm 1.0$ & 64.8 \\
& $5 \times 10^{-3}$ & $34 \pm 2.4$ & 8.1 \\
Histamine & $1 \times 10^{-3}$ & $35 \pm 3.6$ & 5.4 \\
& $1 \times 10^{-7}$ & $33 \pm 3.0$ & 10.8 \\
\hline
\end{tabular}

${ }^{a}$ Drugs were added to the mixture of lymphocytes depleted of adherent cells and K562 target cells and incubated as described under Materials and Methods. Lymphocytes bearing at least one surface-bound target cell were counted in a hemacytometer. Results are expressed as means \pm SEM of three separate experiments.

${ }^{b}$ Minus sign indicates enhancement.

$1 \times 10^{-3} M$ histamine concentration. Table 8 shows the effects of preculture of PBL with histamine on NK and ADCC activities at different E:T cell ratios. Suppression of both NK and ADCC functions of PBL precultured with histamine was evident even at higher E:T cell ratios. Studies on the effects of histamine on lymphocyte subpopulations reveal that $\mathrm{T}$ lymphocytes and Percoll-enriched NK effector cells, when cultured with histamine, also show suppression of their NK activity at different E:T cell ratios (Table 9).

\section{Lymphocytes Preincubated with Histamine Suppress NK Activity of Autologous Normal Lymphocytes}

In coculture experiments to measure suppression, Percoll-separated NK-enriched lymphocytes precultured with histamine were added to a mixture of autologous effector cells and prelabeled target cells at different effector to inhibitor (E:I) ratios. Results are presented in Table 10. At E:I cell ratios of 1:1 or less, lymphocytes precultured with histamine significantly suppressed the NK activity of autologous effector cells. Similar results were obtained when total peripheral blood mononuclear cells were precultured with histamine and tested for their suppressive effect on autologous effector cells in coculture experiments (data not presented).

To rule out the possibility that crowding, steric hindrance, or cell death could cause suppression of NK activity, we examined the effect of (1) normal human RBC, (2) PBL preincubated with histamine and then heat killed $\left(56^{\circ} \mathrm{C}\right.$ for $\left.30 \mathrm{~min}\right)$, and (3) heat-killed effector cells on the NK activity of autologous effector cells. The results demonstrate that the addition of any of these cells as inhibitors to the reaction mixture at E:I cell ratios of $1: 1$ or less did not produce any significant suppression of NK activity by autologous effector cells (data not presented). This suggests that the suppression of NK activity by histamine-induced suppressor cells observed in the present experiments was not caused by crowding, steric hindrance, or cell death, but by functionally active viable suppressor cells. 


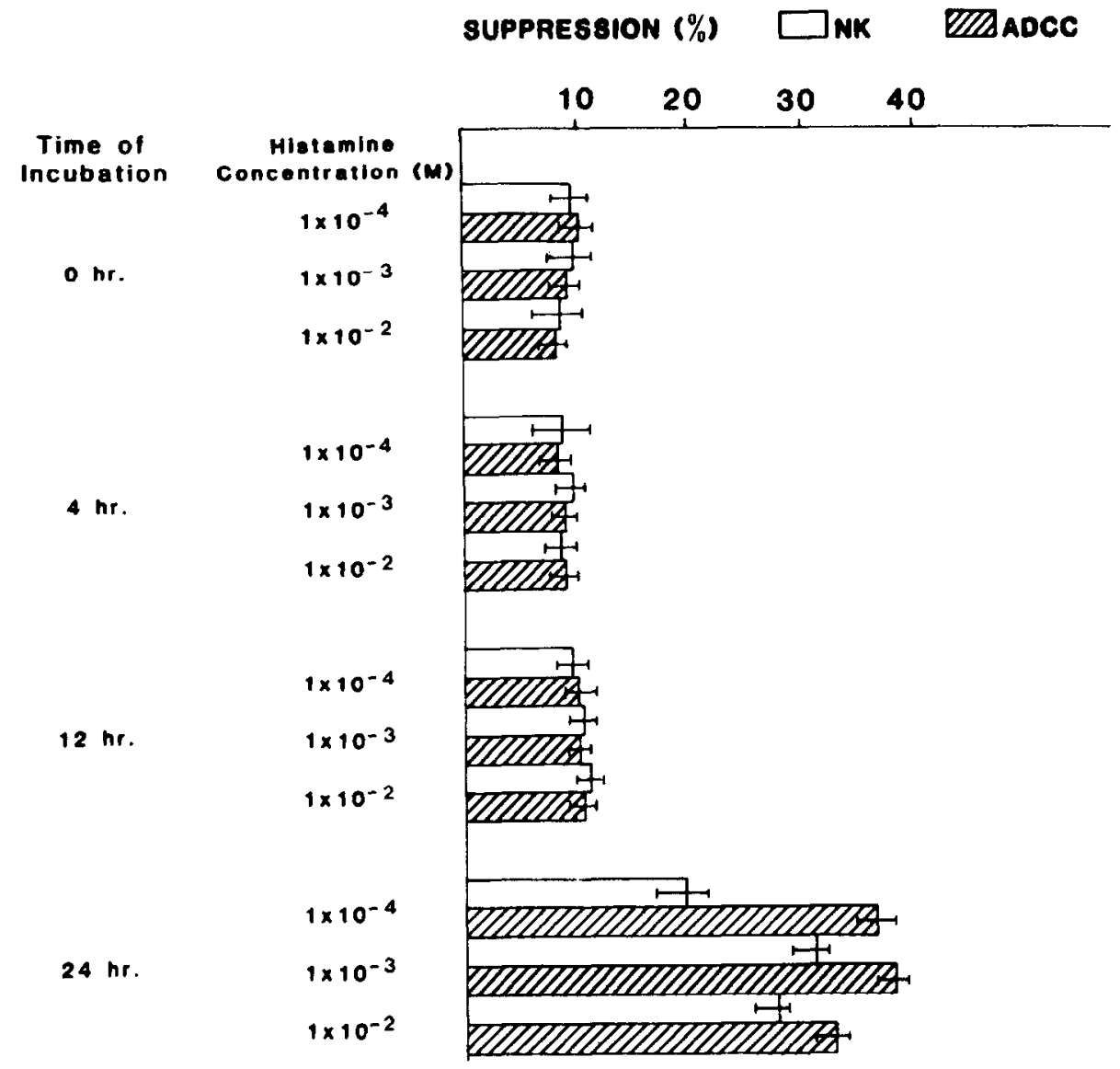

FiG. 1. Time course study of NK and ADCC activities of PBL precultured with histamine. PBL depleted of adherent cells were precultured alone or with histamine $\left(1 \times 10^{-2}\right.$ to $\left.1 \times 10^{-4} \mathrm{M}\right)$ for 0 to $24 \mathrm{hr}$, washed twice, and tested for NK and ADCC activities. Results are expressed as mean percentages of suppression of cytotoxicity \pm SEM of four separate experiments with triplicate determinations for each experiment at a 50:1 E:T cell ratio.

\section{PBL Precultured with Histamine Show Increased Numbers of OKT8 ${ }^{+}$Cells}

As $\mathrm{OKT} 8^{+}$lymphocytes are capable of suppressing various immune reactions $(27$, 28 ), experiments were undertaken to determine if lymphocytes precultured with histamine express increased number of $\mathrm{OKT}^{+}$cells. PBL depleted of adherent cells precultured with histamine $\left(1 \times 10^{-3} M\right)$ for $24 \mathrm{hr}$ were washed and examined for $\mathrm{OKT}^{+}, \mathrm{OKT}^{+}$, and $\mathrm{OKT}^{+}{ }^{+}$subpopulations, using monoclonal antibodies in a complement-dependent cytotoxicity assay (Table 11). PBL precultured with histamine showed no changes in either $\mathrm{OKT}_{3}{ }^{+}$or $\mathrm{OKT} 4^{+}$subpopulations compared to control cultures. However, an $11 \%$ increase in $\mathrm{OKT}^{+}$cells from $21 \%$ to $32 \%$ was observed after preculture with histamine. This suggests that histamine modulates NK and ADCC activities of lymphocytes by activating $\mathrm{OKT} 8^{+}$suppressor cells.

\section{DISCUSSION}

$\mathrm{NK}$ and ADCC cells have been gaining attention because of their proposed role in defense against tumors and in the regulation of various lymphoid cell reactions 
TABLE 8

NK and ADCC Activities of PBL Precultured with Histamine at Various Effector to Target Cell Ratios ${ }^{a}$

\begin{tabular}{|c|c|c|c|c|c|c|}
\hline \multirow{3}{*}{$\begin{array}{c}\text { Histamine } \\
\text { concentration } \\
(M)\end{array}$} & \multicolumn{6}{|c|}{ Cytotoxicity $(\%)^{b}$} \\
\hline & \multicolumn{3}{|c|}{$\mathbf{N K}^{c}$} & \multicolumn{3}{|c|}{$\mathrm{ADCC}^{d}$} \\
\hline & $\mathrm{E}: \mathrm{T}=50: 1^{e}$ & $E: T=20: 1$ & $E: T=10: 1$ & $\mathrm{E}: \mathrm{T}=50: 1$ & $\mathbf{E}: \mathbf{T}=20: 1$ & $E: T=10: 1$ \\
\hline 0 & $40.0 \pm 4.4$ & $32.6 \pm 3.3$ & $20.1 \pm 1.9$ & $42.4 \pm 4.4$ & $27.9 \pm 2.7$ & $16.1 \pm 1.8$ \\
\hline $1 \times 10^{-3}$ & $\begin{array}{c}28.1 \pm 2.4 \\
(29.7)^{f}\end{array}$ & $\begin{array}{c}19.6 \pm 1.8 \\
(39.8)\end{array}$ & $\begin{array}{c}8.5 \pm 0.6 \\
(57.7)\end{array}$ & $\begin{array}{c}28.0 \pm 2.8 \\
\quad(33.9)\end{array}$ & $\begin{array}{c}18.2 \pm 1.6 \\
(34.7)\end{array}$ & $\begin{array}{c}4.7 \pm 0.4 \\
(70.8)\end{array}$ \\
\hline
\end{tabular}

${ }^{a}$ PBL depleted of adherent cells were cultured with or without histamine $\left(1 \times 10^{-3} \mathrm{M}\right)$ for $24 \mathrm{hr}$, washed, and tested for NK and ADCC activities.

${ }^{b}$ Percentage cytotoxicity was calculated as under Materials and Methods.

${ }^{c}$ NK activity was measured against the human erythroleukemia cell line, K562.

${ }^{d}$ ADCC activity was measured against the human B-lymphoblast cell line, SB, sensitized with anti-SB sera.

${ }^{e}$ Effector to target cell ratio.

${ }^{\prime}$ Numbers in parentheses indicate the percentage inhibition. Results are expressed as mean \pm SEM of four experiments.

(29-31). Studies from our laboratory and by others have shown that NK and ADCC activities are also subject to regulation by suppressor cells or their soluble products $(3,5,19,20,31-34)$. Earlier investigations have shown that human $\mathrm{T}$ cells with Fc

TABLE 9

NK Activity of T Cells and NK-Enriched Lymphocytes Precultured with Histamine ${ }^{a}$

\begin{tabular}{|c|c|c|c|c|c|c|}
\hline \multirow{3}{*}{$\begin{array}{c}\text { Histamine } \\
\text { concentration } \\
(M)\end{array}$} & \multicolumn{6}{|c|}{ Cytotoxicity (\%) ${ }^{b}$} \\
\hline & \multicolumn{3}{|c|}{ NK-enriched cells ${ }^{c}$} & \multicolumn{3}{|c|}{ T cells ${ }^{d}$} \\
\hline & $\mathrm{E}: \mathrm{T}=20: 1^{e}$ & $\mathrm{E}: \mathrm{T}=10: 1$ & $\mathrm{E}: \mathrm{T}=5: 1$ & $E: T=50: 1$ & $E: T=20: 1$ & $E: T=10: 1$ \\
\hline 0 & $73.2 \pm 8.6$ & $68.1 \pm 7.9$ & $54.6 \pm 6.7$ & $69.0 \pm 5.5$ & $62.0 \pm 9.2$ & $37.1 \pm 4.5$ \\
\hline $1 \times 10^{-5}$ & $\begin{array}{c}77.2 \pm 7.3 \\
(-5.4)^{f}\end{array}$ & $\begin{array}{c}70.9 \pm 6.7 \\
(-4.1)\end{array}$ & $\begin{array}{c}57.4 \pm 5.3 \\
(-5.1)\end{array}$ & $\begin{array}{c}64.8 \pm 4.3 \\
(6.0)\end{array}$ & $\begin{array}{c}57.2 \pm 5.1 \\
(7.7)\end{array}$ & $\begin{array}{c}39.6 \pm 3.9 \\
(-6.7)\end{array}$ \\
\hline $1 \times 10^{-4}$ & $\begin{array}{c}76.4 \pm 6.6 \\
(-4.3)\end{array}$ & $\begin{array}{c}75.8 \pm 7.8 \\
(-11.3)\end{array}$ & $\begin{array}{c}58.4 \pm 4.8 \\
(-6.9)\end{array}$ & $\begin{array}{c}64.3 \pm 6.6 \\
(6.8)\end{array}$ & $\begin{array}{c}54.7 \pm 5.4 \\
(11.7)\end{array}$ & $\begin{array}{c}27.4 \pm 3.2 \\
(26.1)\end{array}$ \\
\hline $1 \times 10^{-3}$ & $\begin{array}{c}60.1 \pm 5.6 \\
(17.8)\end{array}$ & $\begin{array}{c}50.5 \pm 4.8 \\
(25.8)\end{array}$ & $\begin{array}{c}30.3 \pm 4.3 \\
(44.5)\end{array}$ & $\begin{array}{c}52.8 \pm 2.8 \\
(23.4)\end{array}$ & $\begin{array}{c}23.0 \pm 3.3 \\
(62.9)\end{array}$ & $\begin{array}{c}5.9 \pm 3.8 \\
(84.0)\end{array}$ \\
\hline
\end{tabular}

${ }^{a} \mathrm{~T}$ lymphocytes and Percoll-separated NK-enriched effector lymphocytes were precultured with histamine for $24 \mathrm{hr}$, washed, and tested for NK activity. Values are the means \pm SEM of triplicate determinations for a representative experiment. Three separate experiments gave similar results.

${ }^{b}$ Percentage cytotoxicity was measured against the erytholeukemia cell line, K562, as described under Materials and Methods.

c NK-enriched lymphocytes were separated on a Percoll density gradient as described under Materials and Methods.

T T cells were separated by rosetting as described under Materials and Methods.

Effector to target cell ratio.

${ }^{f}$ Numbers in parentheses are percentage inhibition and a minus sign indicates enhancement. 
TABLE 10

Suppression of Percoll-Enriched NK Cells by Autologous Lymphocytes Precultured with Histamine

\begin{tabular}{|c|c|c|c|c|c|c|}
\hline \multirow{2}{*}{$\begin{array}{l}\text { Effector } \\
\text { cells } \\
(\text { No. })^{a}\end{array}$} & \multirow{2}{*}{ 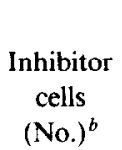 } & \multirow{2}{*}{$\begin{array}{l}\text { Inhibitor } \\
\text { cell } \\
\text { cytotoxicity } \\
(\%)^{c}\end{array}$} & \multirow{2}{*}{$\begin{array}{c}\mathrm{E}: \mathrm{I} \\
\text { ratio }^{d}\end{array}$} & \multicolumn{2}{|c|}{$\begin{array}{l}\text { Effector cell cytotoxicity } \\
(\%)\end{array}$} & \multirow{2}{*}{$\begin{array}{c}\text { Suppression } \\
(\%)^{f}\end{array}$} \\
\hline & & & & Observed $^{c}$ & Predicted $^{e}$ & \\
\hline $2 \times 10^{5}$ & - & - & - & $35.2 \pm 4.2$ & - & - \\
\hline $2 \times 10^{5}$ & $1 \times 10^{6}$ & $24.7 \pm 2.4$ & $1: 5$ & $33.2 \pm 1.2$ & 59.9 & 44.5 \\
\hline $2 \times 10^{5}$ & $8 \times 10^{5}$ & $19.0 \pm 1.2$ & $1: 4$ & $29.3 \pm 2.9$ & 54.2 & 45.9 \\
\hline $2 \times 10^{5}$ & $6 \times 10^{5}$ & $17.4 \pm 2.6$ & $1: 3$ & $28.7 \pm 1.8$ & 52.6 & 45.4 \\
\hline $2 \times 10^{5}$ & $4 \times 10^{5}$ & $18.2 \pm 1.5$ & $1: 2$ & $32.8 \pm 2.4$ & 53.4 & 30.4 \\
\hline $2 \times 10^{5}$ & $2 \times 10^{5}$ & $14.5 \pm 2.8$ & $1: 1$ & $36.4 \pm 3.2$ & 49.7 & 26.7 \\
\hline
\end{tabular}

${ }^{a}$ Percoll-separated NK-enriched lymphocytes precultured in medium alone for $24 \mathrm{hr}$ were used as effectors at an $\mathrm{E}: \mathrm{T}$ ratio of $10: 1$.

${ }^{b}$ Autologous Percoll-enriched lymphocytes were precultured with histamine $\left(10^{-3} M\right)$ for $24 \mathrm{hr}$, washed, and used as inhibitor cells at different ratios.

' Percentage cytotoxicity was measured as described under Materials and Methods.

${ }^{d}$ Effector to inhibitor cell ratio.

e Predicted cytotoxicity equals sum of the percentage of the cytotoxicities of the effector and inhibitor cells measured separately.

${ }^{f}$ Percentage inhibition $=($ predicted $\%$ cytotoxicity observed $\%$ cytotoxicity/predicted $\%$ cytotoxicity $)$ $\times 100$. The results are expressed as the mean \pm SEM of a representative experiment and three other experiments produced similar results.

receptors for $\operatorname{IgG}(\mathrm{T} \gamma$ cells) are involved in NK and $\mathrm{ADCC}$ mechanisms $(6,10)$, as well as in the regulation of other immunologic reactions (8-10).

Recently histamine, a vasoactive amine, has been shown to play a role in immunoregulation $(11,13,24,25,35,36)$. Rocklin et al. (26) reported that $\mathrm{T}$ lymphocytes exposed to histamine in vitro elaborate a soluble factor which suppresses the production of migration inhibition factor and proliferation by sensitized lymphocytes. Szewcznk et al. (37) showed that in vivo injection of histamine with trinitrophenylated bovine $\alpha$-globulin into mice induced the formation of autoanti-idiotypic antibodies, which regulate the immune response to trinitrophenylated bovine $\alpha$-globulin. Beer et al. (12) recently showed that PBL precultured in the presence of histamine $\left(10^{-4}\right.$ to $10^{-3}$ $M$ ) for $24 \mathrm{hr}$ could function as suppressor cells in a coculture experiment. The $\mathrm{T} \gamma$

TABLE 11

Effect of Histamine on T-Cell Subpopulations ${ }^{a}$

\begin{tabular}{cccc}
\hline $\begin{array}{c}\text { Histamine } \\
\text { concentration } \\
(M)\end{array}$ & OKT3 $(\%)$ & OKT4 $(\%)$ & OKT8 (\%) \\
\hline 0 & $62.5 \pm 3.5$ & $22.5 \pm 2.1$ & $21.0 \pm 2.8$ \\
$1 \times 10^{-3}$ & $57.3 \pm 7.7$ & $19.5 \pm 0.7$ & $32.1 \pm 2.7$ \\
\hline
\end{tabular}

\footnotetext{
${ }^{a}$ PBL depleted of adherent cells were cultured alone or with $1 \times 10^{-3} \mathrm{M}$ histamine for $24 \mathrm{hr}$, washed, and tested for lymphocyte subpopulations, using monoclonal antibodies by a complement-dependent cytotoxic assay. The number of positive cells stained with trypan blue were counted, using a hemacytometer. Values represent the mean $\pm \mathrm{SEM}$ of three experiments.
} 
subpopulation, which mediates potent $\mathrm{NK}$ and $\mathrm{ADCC}$ reactions $(6,10)$, has been shown to possess histamine receptors (26). It was of interest, therefore, to cxaminc whether histamine receptor-bearing lymphocytes are involved in the regulation of NK and ADCC activities. We report here a previously unrecognized immunosuppressive effect of histamine on NK and ADCC activities of normal lymphocytes, i.e., lymphocytes precultured with histamine showed significant suppression of NK and ADCC activities, and were able to suppress the NK activity of autologous effector cells in coculture experiments. An immunoregulatory role of histamine for NK and ADCC reactions is thus proposed.

We further demonstrate that the histamine antagonists, clemastine fumarate and cimetidine, when added directly to the reaction mixture of effector and target cells, block NK and ADCC activities in a dose-dependent fashion at different E:T cell ratios. This blocking effect was evident against Percoll-separated NK-enriched effector cells and T lymphocytes. Antihistamine-induced inhibition of cytotoxicity is reversed by the addition of histamine, which at the same dose did not affect NK or ADCC activities when added directly to the reaction mixture. This is consistent with the findings of others (38-42), who demonstrated the blocking effect of NK and ADCC activities by histamine antagonists. This suggests that histamine receptors are involved in these cytotoxic mechanisms and that blocking of such receptors impedes the cytotoxic potential of lymphocytes. In TBC studies, the histamine antagonists, at NK or ADCC inhibitory doses, also reduced the number of target binding lymphocytes. This demonstrates that histamine antagonists interfere with a histamine receptorassociated target in target-effector interactions.

Suppression is operationally defined herein as the inhibition of cytotoxicity of effector lymphocytes after addition of drugs directly into the mixture of effector and target cells, or after preculturing lymphocytes with drugs. The decrease of cylotoxicity is not due to direct cytotoxicity of effector cells, since lymphocytes treated with either clemastine or cimetidine showed normal spontaneous ${ }^{51} \mathrm{Cr}$ release, and the viability was comparable with that of untreated control cultures as measured by trypan blue dye exclusion test (data not presented). Lymphocytes precultured with histamine also showed comparable viability and normal spontaneous release of ${ }^{51} \mathrm{Cr}$ with that of untreated lymphocytes (data not presented).

The natural history of effector cells involved in NK or ADCC mechanisms is still not clearly understood. In the human system, evidence indicates that at least some of the NK cells may belong to the T-lymphocyte lineage (43-45). The blocking of T-cell-mediated NK activities by histamine antagonists and the induction of suppressor cell activity by preculturing $\mathrm{T}$ cells with histamine may support a $\mathrm{T}$-cell lineage of some NK effector cells. Our study further reveals that histamine exerts a suppressive effect on Percoll-separated NK-enriched effector cells, and histamine-induced suppressor cells were able to inhibit the NK activity of normal cells in autologous coculture experiments.

It has been shown that suppressor $\mathrm{T}$ cells are recognized by OKT8 monoclonal antibodies and that such $\mathrm{T}$ cells are known to suppress several immunologic functions $(27,28)$. We have examined the number of OKT $8^{+} \mathrm{T}$ cells present in the T-lymphocyte population precultured with histamine and have demonstrated an increase in the number of $\mathrm{OKT}^{+}$cells. The number of $\mathrm{OKT}^{+}$and $\mathrm{OKT} 4^{+}$subpopulations, however, remained unchanged suggesting that $\mathrm{OKT}^{+}$cells are either recruited from precursors or from $\mathrm{OKT}^{+}$or $\mathrm{OKT}^{+}$subpopulations by histamine. It is thus possible that 
histamine-treated PBL may exhibit a complex phenotype with coexpression of OKT3, OKT4, and OKT8 markers. These questions are presently under investigation in our laboratory. This supports the premise that histamine activates $\mathrm{OKT} 8^{+}$cells to express suppressor effects on NK and ADCC reactions.

The present report demonstrates that lymphocytes with histamine receptors are involved in NK and ADCC reactions and can be activated upon culturing with histamine to express suppressor functions. This dual role of histamine receptor-bearing lymphocytes in the mediation and regulation of NK and ADCC mechanisms merits further study. Examination of any deficiencies of NK and ADCC activities in certain allergic, inflammatory or immunologically mediated diseases associated with vasoactive amines such as histamine and its antagonists, has important clinical significance.

\section{ACKNOWLEDGMENTS}

The authors wish to express their sincere appreciation to Mary Burton for her technical assistance, and to Ms. Joan McClain for her expert secretarial assistance.

\section{REFERENCES}

1. Shou, L., Schwartz, S. A., and Good, R. A., J. Exp. Med. 143, 1100, 1976.

2. Schwartz, S. A., Shou, L., Good, R. A., and Choi, Y. S., Proc. Nall. Acad. Sci. USA 74, 2099, 1977.

3. Nair, M. P. N., and Schwartz, S. A., J. Immunol. 126, 2221, 1981.

4. Shou, L., Schwartz, S. A., Good, R. A., Peng, R., and Chen, C. L., Proc. Natl. Acad. Sci. USA 77, $6096,1980$.

5. Nair, M. P. N., and Schwartz, S. A., J. Immunol. 129, $2511,1982$.

6. Gupta, S., Fernandes, G., Nair, M., and Good, R. A., Proc. Natl. Acad. Sci. 75, 5137, 1978.

7. West, W., Cannon, G. B., Kay, H. D., Bonnard, G. D., and Herberman, R. B., J. Immunol. 118, 355, 1977.

8. Grossi, G. E., Webb, S. R., Zicca, A., Lydyard, P. M., Moretta, L., Mingari, M. C., and Cooper, M. D., J. Exp. Med. 147, 1405, 1978.

9. Moretta, L., Webb, S. R., Grossi, C. E., Lydyard, P. M., and Cooper, M. D., J. Exp. Med. 146, 184, 1977.

10. Jondal, M., and Merrill, J. E., Eur. J. Immunol. 11, 531, 1981.

11. Damle, N. K., and Gupta, S., J. Clin. Immunol. 1, 241, 1981.

12. Beer, D. J., Rosenwasser, L. J., Dinarello, C. A., and Rocklin, R. E., Cell. Immunol. 69, 101, 1982.

13. Rocklin, R. E., J. Clin. Invest. 57, 1051, 1976.

14. Rocklin, R. E., Greineder, D. K., and Melman, K. L., Cell. Immunol. 44, 404, 1979.

15. Suzuki, S., and Hunchet, R., Cell. Immunol. 68, 349, 1982.

16. Böyum, A., J. Clin. Lab Invest. 21(Suppl. 97), 77, 1968.

17. Gupta, S., Schwartz, S. A., and Good, R. A., Cell. Immunol. 44, 242, 1979.

18. Timonen, T., and Saksela, E., J. Immunol. Methods 36, 285, 1980.

19. Nair, P. N. M., Fernandes, G., Ońoe, K., Day, N. K., and Good, R. A., Int. J. Cancer 25, 667, 1980.

20. Nair, M. P. N., Schwartz, S. A., Fernandes, G., Pahwa, R., Ikehara, S., and Good, R. A., Cell. Immunol. 58, 9, 1981 .

21. Perlmann, P., and Perlmann, H., Cell. Immunol. 1, 300, 1970.

22. Handwerger, B. S., and Koren, H. S., Clin. Immunol. Immunopathol 5, 272, 1976.

23. Haliotis, T., Roder, J., Klein, M., Ortaldo, J., Fauci, A. S., and Herberman, R. B., J. Exp. Med. 151, $1039,1980$.

24. Plant, M., Lichtenstein, L. M., and Henney, C. S., J. Clin. Invest. 55, 856, 1975.

25. Ballet, J. J., and Merler, E., Cell. Immunol. 25, 250, 1976.

26. Rocklin, R. E., Breard, J., Gupta, S., Good, R. A., and Melman, K. L., Cell. Immunol. 51, $226,1980$.

27. Thomas, Y., Sosman, J., Rogozinski, L., Irigoyen, O., Kung, P. C., Goldstein, G., and Chess, L., J. Immunol. 126, 1948, 1951.

28. Thomas, Y., Sosman, J., Irigoyen, O., Friedman, S. M., Kung, P. C., Goldstein, G., and Chess, L., J. Immunol. 125, 2402, 1980. 
29. O'Toole, C., Stejskal, V., Perlmann, P., and Karlson, M., J. Exp. Med. 139, 457, 1974.

30. Wasserman, J., Vonstedingk, L. V., Perlmann, P., and Johnson, J., Int. Arch. Allergy Appl. Immunol. 47, 473, 1974.

31. Herberman, R. B., and Holden, T., Advan. Cancer Res. 27, 305, 1978.

32. Cudkowicz, G., and Hochman, P. S., Immunol. Rev. 44, 13, 1979.

33. Cudkowicz, G., and Hochman, P., In "Developmental Immunobiology. Fifth Irwin Strasburger Memorial Seminar on Immunology" (G. W. Siskind, S. D. Litwin, and M. E. Weksler, Eds.), p. 1. Grune \& Stratton, New York, 1979.

34. Pollack, S. B., and Emmons, S. I., J. Immunol. 122, 718, 1979.

35. Wang, S. R., and Zweiman, R., Cell. Immunol. 36, 28, 1978.

36. Plant, M., Lichtenstein, L. M., Gillespie, E., and Henney, C. S., J. Immunol. 111, 389, 1973.

37. Szewcznk, M. R., Campbell, R. J., and Smith, J. W., Cell. Immunol. 65, 152, 1981.

38. Paronillo, J. E., and Fauci, A. S., Annu. Rev. Pharmacol. Toxicol. 19, 179, 1979.

39. Miller, M. L., and Pachman, L. M., J. Pediatr. 98, 1021, 1981.

40. Ruiz-Argüelles, A., Seroogy, K. B., and Ritts, R. E., Jr., Cell. Immunol. 69, 1, 1982.

41. Láng, I., Gergely, P., and Petrányi, G. Y., Scand. J. Immunol. 14, 573, 1981.

42. Láng, I., Török, K., Gergely, P., Nékám, K., and Petrányi, G. Y., Scand. J. Immunol. 13, 361, 1981.

43. Powles, R. L., Barrett, A. J., Clink, H., Kay, H. E. M., Sloane, J., and Elwain, T. J., Lancet 2, 1327, 1978.

44. Powles, R. L., Clink, H. M., Spence, D., Morganstern, G. J., Watson, J. G., Selby, P. J., Woods, M., Barrett, A., Jameson, B., Sloane, J., Lawler, S. D., Kay, H. E. M., Lawson, D., McElwin, T. J., and Alexander, P., Lancet 1, 327, 1980.

45. Herberman, R. B., Djeu, J. Y., Kay, H. D., Ortaldo, J. R., Riccardi, C., Bonnard, G. D., Holden, H. T., Fagnoni, R., Santoni, A., and Puccetti, P., Immunol. Rev. 44, 43, 1979. 